JIKAP PGSD: Jurnal IImiah Ilmu Kependidikan

Vol,3. No,2. Tahun 2019

e-ISSN: 2597-4440 dan p-ISSN: 2597-4424

(c) (1) This work is licensed under a Creative Commons Attribution

4.0 International License

\title{
Penggunaan Pendekatan Keterampilan Proses Untuk Meningkatkan Pemahaman Siswa Tentang Konsep Energi Bunyi Di Kelas Vi Sd Negeri 110 Pompanua Kabupaten Bone
}

\author{
Asiah \\ Dinas Pendidikan Kabupaten Bone \\ Email: asiah@gmail.com
}

\begin{abstract}
Abstrak. Permasalahan dalam penelitian ini adalah sebagai berikut: apakah dengan pembelajaran pendekatan keterampilan proses dapat meningkatkan pemahaman siswa tentang konsep energi bunyi di Kelas VI SD Negeri 110 Pompanua Kab. Bone. Sumber data dalam penelitian ini adalah personil penelitian yang terdiri dari siswa dan guru. Jenis data yang diperoleh adalah kuantitatif dan data kualitatif yang terdiri dari tes hasil belajar, hasil observasi, evaluasi, refleksi dan hasil wawancara. Hasil penelitian menunjukan bahwa ada peningkatan yang berarti baik pada aktivitas guru dan siswa pada saat proses belajar maupun hasil belajar memahami konsep energi bunyi. Peningkatan itu dapat terlihat pada setiap siklus kesiklus. Siklus satu tingkat penguasaan siswa cukup (C), siklus dua tingkat penguasaan siswa baik (B). Dari hasil penelitian dan pembahasan diperoleh kesimpulan bahwa pembelajaran dengan menggunakan pendekatan keterampilan proses yang dapat meningkatkan pemahaman siswa dalam pengajaran konsep energi bunyi di SD Negeri 110 Pompanua adalah sebagai berikut: (a) Mengamati, (b) Menggolongkan/ mengkalsifikasi, (c) Menafsirkan, (d) Merencanakan penelitian, (e) Meramalkan, dan (f) Menerapkan, (g) Mengkomunikasikan, dan (h) Evaluasi. Saran Peneliti adalah kepada guru SD, agar menggunakan pendekatan keterampilan proses sebagai salahsatu alternatif meningkatkan pemahaman konsep dalam pembelajaran energi bunyi di SD.
\end{abstract}

Kata kunci: pendekatan keterampilan proses, pemahaman konsep

\begin{abstract}
The problems in this study are as follows: whether learning process approaches can improve students' understanding of the concept of sound energy in Class VI SD Negeri 110 Pompanua Kab. Bone. Sources of data in this study are research personnel consisting of students and teachers. The types of data obtained are quantitative and qualitative data consisting of learning outcomes tests, observations, evaluations, reflections and interview results. The results of the study show that there is an increase which means both the activities of teachers and students during the learning process and the results of learning to understand the concept of sound energy. This increase can be seen in each cycle of cycles. Cycle one level of student mastery is sufficient (C), cycle two levels of mastery of good students (B). From the results of the research and discussion, it was concluded that learning using a process skills approach that could improve students' understanding of sound energy concept teaching in 110 Public Schools in Pompanua was as follows: (a) Observing, (b) Classifying / calcifying, (c) Interpreting, (d) Planning research, (e) Predicting, and (f) Applying, (g) Communicating, and (h) Evaluation. The Researcher's suggestion is for elementary school
\end{abstract}


JIKAP PGSD: Jurnal Ilmiah Ilmu Kependidikan

teachers to use the process skills approach as one of the alternatives to improve the understanding of concepts in sound energy learning in elementary schools.

Keywords: process skills approach, concept understanding

\section{PENDAHULUAN}

Sains merupakan ilmu yang membahas tentang gejala-gejala alam yang disusun secara sistematis yang didasari oleh fakta yang empiral pada hasil percobaan dan pengamatan yang dilakukan oleh manusia. Hal ini sebagaimana yang dikemukakan oleh Powder ( Wina Putra, 1992: 122) bahwa Sains merupakan ilmu yang berhubugan dengan gejala-gejala alam dan kebendaan yang sistematis yang tersusun secara teratur, berlaku umum yang berupa kumpulan dari hasil observasi dan eksperimen serta data yang lebih nyata.

Berdasarkan hal di atas, yang terpenting dalam pembelajaran Sains di SD Negeri 110 Pompanua adalah bagaimana menggali berbagai pengetahuan baru pada diri anak didik terutama dalam mengembangkan kognitif, afektif, psikomotor dan kreatifitas. Hal ini sejalan dengan Abruscato (1992) yang mengungkapkan bahwa pembelajaran Sains di SD Negeri 110 Pompanua mengembangkan, 1) kognitif siswa, 2) mengembangkan afektif sisiwa, 3) mengembangkan psikomotorik siswa, 4) mengembangkan kreatifitas siswa, dan 5) melatih siswa untuk berpikir kritis.

Dalam Kurikulum Tingkat Satuan Pendidikan (KTSP) Sains Kelas VI Sekolah Dasar, ada beberapa kajian materi yang harus dikuasai siswa sekolah dasar. Salah satu mengembangkan keterampilan Sains bagi siswa yang diperlukan kemampuan aktivitas pembelajaran dalam bentuk keterampilan proses sains, diantaranya adalah mengamati, mengklasifikasi, memprediksi, dan mengkomunikasikan.

Sains diyakini sebagai pelajaran yang penting dan sesuai dengan karakteristik siswa SD, karena Sains dapat mengungkap pengetahuan alam semesta yang berkaitan dengan lingkungan sekitarnya. Sejalan dengan Samatowa (2006: 78) mengemukakan bahwa dengan belajar Sains, dapat meningkatkan kemampuan siswa kearah sikap dan kemampuan yang baik dan berguna bagi lingkungan.
Namun pada kenyataannya, pembelajaran Sains di SD Negeri 110 Pompanua belum sesuai harapan. Hal ini disebabkan karena cara pengajaran guru yang konvensional (ceramah dan tanya jawab). Guru dalam mengajar hanya mengejar target kurikulum tanpa memperhatikan apakah konsep yang diajarkan sudah dipahami oleh siswa, selain itu guru lebih banyak menggunakan metode ceramah tanpa melakukan pendekatan dan percobaan-percobaan secara langsung. Di sekolah SD Negeri 110 Pompanua di jumpai masalah-masalah, yaitu siswa mendapakan nilai-nilai rendah, karena siswa kurang mampu menerapkan pemerolehannya, baik berupa pengetahuan, keterampilan, maupun sikap dalam kehidupan yang nyata. Hal ini disebabkan karena materi pelajaran Sains diterima hanya melalui informasi verbal. Siswa tidak dibiasakan aktif mencoba sendiri pengetahuan atau informasi dalam kehidupan nyata.

Kondisi di atas juga terjadi di SD Negeri 110 Pompanua, khususnya pada Kelas VI. Hal ini terungkap melalui prapenelitian pada tahun 2018 melalui pengamatan dan wawancara kepada guru dan siswa Kelas VI SD Negeri 110 Pompanua.

Hasil pengamatan dan wawancara yang dilakukan peneliti pada prapenelitian terhadap guru dan siswa ditemukan salah satu konsep yang masih sulit dipahami siswa adalah konsep energi bunyi. Selama ini dalam mengajarkan materi tentang energi bunyi (1) guru kebanyakan menggunakan metode ceramah, sehingga mengakibatkan kegiatan pembelajaran terbatas dan siswa cepat bosan dalam kegiatan pembelajaran, (2) guru kurang melibatkan siswa dihadapkan pada lingkungan belajar yang konkrit, dalam memanipulatif alat peraga, artinya meskipun ada alat peraga tetapi hanya guru yang menggunakan tanpa memeberi kesempatan kepada siswa untuk melakukan percobaan-percobaan yang dapat memberikan pengalaman dan meningkatkan kreatifitas siswa, (3) guru kurang memahami arti pendekatan keterampilan proses seperti menggamati, menggolongkan, menafsirkan, meramalkan, menerapkan, merencanakan 
penelitian,dan menggkomunukasikan, sehingga tidak memberikan kesempatan kepada siswa untuk menggunakannya. (4) rendahnya pemahaman siswa pada materi energi bunyi, ini terlihat dari ketidakmampuan siswa dalam menyelesaikan soal latihan pada tes materi energi bunyi. Hasil tes awal sebelum tindakan dari 18 siswa Kelas VI SD Negeri 110 Pompanua yaitu: satu orang siswa mendapat nilai $80(5,5 \%)$, empat orang mendapat nilai $70(38 \%)$, empat orang mendapat nilai 60 $(33 \%)$, tiga orang siswa mendapat nilai $50(27 \%)$, dua orang siswa mendapat nilai $40(22 \%)$, tiga orang siswa mendapat nilai $30(16 \%)$, dan satu orang siswa mendapat nilai $20(11 \%)$. Secara klasikal rata-rata $27 \%$. Padahal yang terpenting dalam pembelajaran Sains adalah mengaktifkan siswa dengan melakukan percobaan-percobaan sehingga mereka dapat menemukan sendiri

Memperhatikan cara pengajaran yang digunakan guru dalam mengajarkan energi bunyi pada Kelas VI SD Negeri 110 Pompanua maka perlu dicarikan solusi pemecahannya. Adapun solusi pemecahan yang digunakan untuk membantu siswa Kelas VI SD Negeri 110 Pompanua dalam meningkatkan pemahaman konsep energi bunyi adalah melalui penerapan pendekatan keterampilan proses dengan menggunakan alat peraga untuk melakukan percobaan yang cocok diterapkan pada materi energi bunyi, agar motivasi belajar siswa meningkat dan proses belajar dapat lebih efektif dan efesien.

Keterampilan proses dalam pembelajaran Sains berarti guru memandang siswa adalah subyek belajar yang diharapkan dapat mengembangkan kognitif, afektif, dan psikomotorik dengan baik. Hal ini sesuai yang dikemukakan oleh Hedriani (1995: 5) sebagai berikut keterampilan proses adalah keterampilan intelektual sosial maupun sosok yang diperlukan untuk dapat mengembangkan lebih lanjut pengetahuan atau konsep yang dimiliki. Dengan dimilikinya keterampilan ini siswa berpeluang untuk dapat memperoleh konsep-konsep baru atau informasi-informasi baru.

Memberi aktivitas keterampilan proses Sains berdampak positif bagi siswa. Hal ini sejalan dengan Pudjiadi (1996: 5) bahwa, siswa dapat berminat dalam mempelajari Sains apabila diberi kesempatan melakukan aktivitas proses Sains melalui mengamati secara nyata atau dengan mencobakan proses Sains yang telah disiapkan dari pada diberi pengajaran secara verbal.

Berdasarkan temuan-temuan masalah pembelajaran konsep energi bunyi tersebut di atas maka penulis sebagai pelaksana penelitian tindakan kelas (PTK) akan melakukan tindakan perbaikan pembelajaran. Adapun pokok bahasan yang dipilih adalah energi bunyi, hal ini sesuai dengan kurikulum 2006 (KTSP) bahwa untuk pokok bahasan ini dipelajari pada Kelas VI. Oleh karena itu perlu diadakan penelitian dengan judul Penggunaan Pendekatan Keterampilan Proses Untuk Meningkatkan Pemahaman Siswa Tentang Konsep Energi Bunyi di Kelas VI SD Negeri 110 Pompanua Kabupaten Bone .

\section{METODE PENELITIAN}

Pendekatan ini menggunakan rancangan Penelitian Tindakan Kelas (Action Researcah), yaitu rancangan penelitian berdaur ulang (siklus) hal ini mengacu pada pendapat MC. Taggart (1998: 123) dan Wardani (2007: 5) bahwa penelitian tindakan kelas mengikuti proses siklus atau daur ulang mulai dari perencanaan, pelaksanaan, observasi dan refleksi (perenungan, pemilihan, dan evaluasi) tahapan tindakan digambarkan dalam bagan 3.1 berikut ini.

Subjek penelitian adalah siswa Kelas VI SD Negeri 110 Pompanua berjumlah 18 orang yang terdiri 14 orang putra dan 4 orang putri. Memilih siswa Kelas VI sebagai responden dengan alasan: (1) Adanya variasi siswa dilihat dari status sosial, pendidikan, dan pekerjaan orang tua mereka, (2) Adanya masalah yang dialami siswa Kelas VI SD Negeri 110 Pompanua dalam belajar memahami konsep energi bunyi, (3) Dilihat dari tingkat kemampuan (prestasi) belajar mata pelajaran Sains pada semester satu sangat rendah.

Penelitian ini akan dilaksanakan di Kelas VI SD Negeri 110 Pompanua Kabupaten Bone Bone. Pelaksanaan penelitian direncanakan pada semester genap tahun pelajaran 2017/2018 selama 6 bulan, waktu tersebut dimulai dari tahap laporan yang dimulai dari dua siklus.

Operasionalisasi Variabel pada penelitian ini terdiri dari variabel bebas dan terikat. Variabel bebas dalam penelitian ini adalah pengajaran dengan menggunakan pembelajaran pendekatan keterampilan proses. Sedangkan, variabel terikat dalam penelitian ini adalah meningkatkan 
pemahaman siswa tentang konsep energi bunyi di Kelas VI SD Negeri 110 Pompanua Kab. Bone.

Penelitian ini terdiri dari dua siklus. Tiap siklus dilaksanakan sesuai dengan adanya perubahan yang ingin dicapai. Adapun langkahlangkah yang akan peneliti laksanakan yaitu: perencanaan, tindakan, observasi, evaluasi, dan refleksi.

Untuk pengumpulan data dalam penelitian ini dilakukan dengan tes, wawancara, pengamatan, dan catatan lapangan. Empat teknik tersebut diuraikan sebagai berikut:

1. Tes

Tes dilakukan bertujuan untuk mengumpulkan informasi tentang pemahaman siswa terhadap konsep energi bunyi. Tes dilaksanakan pada awal penelitian, bertujuan untuk mengetahui kemampuan awal yang dimiliki siswa dalam meningkatkan pemahaman konsep energi bunyi. Pada akhir setiap tindakan, dan pada akhir tiap selesai melakukan serangkaian tindakan (tes akhir) bertujuan untuk melihat peningkatan siswa mengikuti pembelajaran pemahaman konsep energi bunyi melalui pendekatan keterampilan proses.

2. Wawancara

Wawancara bertujuan untuk memperoleh informasi dari siswa mengenai strategi yang digunakan oleh guru dalam meningkatkan pemahaman konsep energi bunyi. Apakah dengan pembelajaran dengan menggunakan konsep energi bunyi dapat meningkatkan pemahaman siswa?

3. Observasi

Observasi bertujuan untuk mengetahui kesesuaian antara perencanaan dan tindakan yang telah disusun serta untuk mengetahui sejauh mana pelaksanaan tindakan dapat menghasilkan perubahan yang susuai dengan yang dikehendaki.

4. Catatan Lapangan

Catatan lapangan bertujuan untuk mencatat hal-hal penting yang terjadi selama pelaksanaan berlangsung yang dapat digunakan untuk melengkapi data yang tidak terekam dalam lembar observasi

Analisis data dilakukan dengan cara mengelompokan data aspek guru dan siswa, menyajikan data, menafsirkan data, dan menyimpulkan. Data aspek guru dan siswa dalam proses pembelajaran dianalisis berdasarkan kemunculan indikator. Sedangkan data hasil konsep energi bunyi dianalisis berdasarkan mengerjakan tes akhir formatif tiap-tiap siklus 1 dan 2. dengan indikator dapat dilihat pada tabel 3.2 sebagai berikut.

Meningkatkan pembelajaran pada aspek guru dan siswa digunakan acuan dengan rumus: $\frac{\text { frekwensi }}{\text { jumlahresponden }} \times 100 \%$

Selanjutnya data ditingkatkan dengan menggunakan rentang taraf keberhasilan seperti dalam tabel 3.2 berikut ini

Tabel 3.2 Taraf Kualifikasi Tindakan Pembelajaran

\begin{tabular}{ccc}
\hline No. & Taraf Keberhasilan & Kualifiasi \\
\hline 1. & $85 \%-100 \%$ & Sangat Baik (SB) \\
\hline 2. & $70-84 \%$ & Baik (B) \\
\hline 3. & $55 \%-69 \%$ & Cukup (C) \\
\hline 4. & $46 \%-54 \%$ & \multicolumn{2}{c}{ Kurang (K) } \\
\hline 5. & $0 \%-45 \%$ & Sangat Kurang (SK) \\
\hline & Setiap jenis & obyek yang dimulai
\end{tabular}
diksifikasi dan ditemukan kecenderungan kategori yaitu sangat baik (SB) jika semua dekrpitif muncul, kualifikasi baik (B) jika 1 deskriptor tidak muncul kualifikasi cukup (C) jika 3 deskriptor muncul kualifikasi kurang (K) jika 2 deskriptor muncul dan dikategorikan sangat kurang (SK) jika deskriptor muncul dan dikategorikan sangat kurang (SK).

Indikator keberhasilan dalam penelitian ini ada dua macam, yaitu indikator tentang keterlaksanaan skenario pembelajaran dan indikator pemahaman konsep energi bunyi . Skenario pembelajaran terlaksana dengan baik apabila pembelajaran telah terlaksana dengan tuntas. Seluruh siswa yang menjadi objek dalam penelitian ini dikatakan memahami konsep energi bunyi yang diajarkan apabila siswa telah memperoleh nilai 7,0.

Kriteria yang digunakan untuk mengungkap kan kemampuan siswa adalah sesuai dengan kriteria standar yang diungkapkan Nurkancana (1986: 39) sebagai berikut:

"Tingkat penguasaan 90\%-100\% dikategorikan sangat tinggi, $80 \%$ $89 \%$ dikategorikan tinggi, $65 \%-79 \%$ sedang, $55 \%-64 \%$ dikategorikan rendah dan $0 \%-54 \%$ dikegorikan sangat rendah". 


\section{HASIL DAN PEMBAHASAN}

Hasil penelitian yang terdiri dari aktivitas guru dan siswa dan hasil belajar pemahaman siswa tentang konsep energi bunyi melalui pendekatan keterampilan proses melalui delapan tahap yaitu mengamati, menggolongkan/mengklasifikasi, menafsirkan, merencanakan penelitian, meramalkan, menerapkan, mengkomunikasikan, dan evaluasi. Berikut adalah paparan tentang hasil pembelajaran siklus I dan siklus II yang terdiri atas perencanaan, pelaksanaan, hasil observasi, evaluasi dan refleksi. Kelima hal tersebut diuraikan hal tersebut.

\section{Data Siklus 1 Aspek Guru dan Siswa}

Temuan penelitian tentang keberhasilan guru dengan menggunakan pendekatan keterampilan proses dalam pembelajaran energi bunyi pada siklus pertama menunjukan bahwa, dari 8 indikator yang harus dicapai guru pada siklus pertama ini direncanakan, terdapat $4(50 \%)$ indikator yang dilaksanakan dengan baik oleh guru, sehingga dikategorikan kurang (K) . 4 (50\%) indikator yang belum dilakukan guru adalah (1) guru tidak membimbing siswa untuk menerapkan peristiwa antara energi bunyi dalam kehidupan sehari-hari, (2) guru tidak membimbing siswa untuk menafsirkan setiap kelompok untuk mencatat hasil pengamatan siswa, (3) guru tidak membimbing siswa untuk menarik kesimpulan setelah melakukan percobaan setiap perkelompok, (4) guru tidak membimbing siswa untuk melakukan tanya jawab. Secara rinci keberhasilan. Berdasarkan refleksi data pada siklus peratama dapat disimpulkan bahwa pencapaian implementasi rencana pembelajaran konsep energi bunyi aspek guru adalah kurang (C). Penyebab guru kurang mencapai indikator yang diharapkan yaitu guru kurang melakukan semua kegiatan yang direncanakan, yaitu langkah-langkah kegiatan mengajar, guru kurang membimbing siswa dalam pembagian kelompok, guru kurang memberikan kesempatan kepada siswa untuk bertanya dan guru kurang menggali pengetahuan awal siswa

Kurangnya guru dalam mencapai indikator yang telah ditentukan, berpengaruh terhadap aktivitas siswa dalam proses pembelajaran energi bunyi, untuk lebih jelasnya hasil aktivitas siswa dalam proses pembelajaran energi bunyi dengan menggunakan pendekatan keterampilan proses, dapat dilihat pada tabel 4.1 dibawah ini.

Tabel 4.1 Data hasil aktivitas dalam proses pembelajaran siklus satu.

\begin{tabular}{clccc}
\hline No & \multicolumn{1}{c}{ Indikator } & Frekuesi & Skor(\%) & Kualifikasi \\
\hline 1. & $\begin{array}{l}\text { Siswa mengemukakan pertanyaan tentang hal-hal apa yang } \\
\text { belum dimengerti, serta meminta siswa untuk } \\
\text { mengemukakan gagasan untuk memecahkan masalah }\end{array}$ & 13 & B \\
\hline 2. & $\begin{array}{l}\text { Siswa melakukan kegiatan mengamati masalah yaitu siswa } \\
\text { mengumpulkan data atau informasi yang sesuai dengan } \\
\text { materi energi bunyi }\end{array}$ & 10 & $55 \%$ & $\mathrm{C}$ \\
\hline 3. & $\begin{array}{l}\text { Siswa mengolongkan-golongkan dan mengkalasifikasi } \\
\text { masalah berdasarkan data dan informasi awal yang telah } \\
\text { ditemukan untuk memecahkan masalah, yaitu } \\
\text { mengolongkan antara sumber energi bunyi }\end{array}$ & 10 & $55 \%$ & $\mathrm{C}$ \\
\hline 4. & $\begin{array}{l}\text { Siswa mengemukakan pemahaman sementara terhadap } \\
\text { materi yang terkumpul berdasarkan data dan informasi awal, } \\
\text { kemudian menghubungkannya dengan kenyataan yang ada } \\
\text { dilingkungan sekitar }\end{array}$ & 13 & $72 \%$ & $\mathrm{~B}$ \\
\hline Siswa menyelidiki masalah dengan melakukan percobaan \\
$\begin{array}{l}\text { untuk menguatkan pemahaman awal siswa terhadap energi } \\
\text { bunyi }\end{array}$
\end{tabular}


JIKAP PGSD: Jurnal Ilmiah Ilmu Kependidikan

\begin{tabular}{lllll}
\hline 7. $\begin{array}{l}\text { Siswa mengaplikasikan pemahamannya dalam bersikap dan } \\
\text { bertingkah laku serta mengkomunikasikan pemahamannya } \\
\text { dalam kegiatan bertanya, menjelaskan, serta menyusun } \\
\text { laporan, dari proses yang mereka lakukan. }\end{array}$ & 10 & $55 \%$ & C \\
\hline 8. & Guru mengevaluasi dan menilai hasil kerja siswa & 18 & $100 \%$ & SB \\
\hline
\end{tabular}

Dari data tabel 4.1 keberhasilan siswa di atas menunjukan bahwa data aktivitas siswa dalam pembelajaran konsep energi bunyi dengan menggunakan pendekatan keterampilan proses yang terdiri dari 18 siswa pada siklus pertama menunjukan bahwa hanya 13 siswa yang mengamati masalah sesuai dengan materi energi bunyi, 10 orang siswa (55\%) menggolongkan dan mengklasifikasi sumber energi bunyi, 10 orang siswa $(55 \%)$ pada siklus 1 menunjukan bahwa hanya 10 siswa $(55 \%)$ yang dapat menafsirkan masalah tentang materi yang diajarkan, 5 siswa $(27 \%)$ yang dapat meramalkan kegiatan yang dilakukan untuk melakukan percobaan, 3 siswa (16\%) yang bisa menerapkan pemahamannya tentang energi bunyi, 3 Siswa (16\%) yang bisa merencanakan apa yang dilakukan dalam percobaan, 10 siswa (55\%) yang mengkomunikasikan dan menyimpulkan pelajaran tentang materi yang dibawakan, 13 siswa (72\%) yang mengerjakan tes formatif.
Berdasarkan refleksi data aktivitas pada siklus pertama dapat disimpulkan bahwa pemahaman konsep energi bunyi melalui pendekatan keterampilan proses yang terdiri dari 8 tahap yaitu mengamati, menggolongkan/mengkalsifikasi, menafsirkan, merencanakan penelitian, meramalkan, menerapkan, mengkomunikasikan, dan evaluasi dikategorikan $\operatorname{cukup}(\mathrm{C})$.

Aktivitas siswa dan guru pada siklus 1, berpengaruh terhadap keberhasilan siswa dalam mengerjakan tes formatif akhir siklus 1 dalam meningkatkan konsep energi bunyi hal ini menjelaskan pengertian energi bunyi, menyebutkan 3 macam bunyi, menyebutkan 3 contoh sumber energi bunyi,menjelaskan fungsi pemantulan bunyi, menyebutkan 3 contoh benda yang dapat menyerap permukaan lunak dalam menggunakan pendekatan keterampilan proses.

Tabel 4.2 Data Hasil Belajar Siswa Siklus 1

\begin{tabular}{llccc}
\hline No & Pemahaman siswa terhadap konsep energi bunyi & Frekuensi & Presentase & Kualifikasi \\
\hline 1. & Mampu menjelaskan pengertian energi bunyi & 13 & $72 \%$ & B \\
\hline 2. & Mampu menyebutkan 3 macam bentuk energi & 10 & $55 \%$ & $\mathrm{C}$ \\
\hline 3. & Mampu menyebutkan 3 contoh energi & 10 & $55 \%$ & $\mathrm{C}$ \\
\hline 4. & Mampu menjelaskan manfaat pemantulan bunyi & 12 & $66 \%$ & $\mathrm{C}$ \\
\hline 5. & $\begin{array}{l}\text { Mampu menentukan 4 contoh yang dapat menyerap } \\
\text { pada permukaan lunak }\end{array}$ & 9 & $50 \%$ & $\mathrm{C}$ \\
\hline
\end{tabular}

Dari tabel 4.2 di atas menunjukan bahwa dalam peningkatan pemahaman konsep energi bunyi dengan menggunakan pendekatan keterampilan proses dari 18 siswa pada siklus pertama menunjukan bahwa hanya 13 (72\%) orang siswa yang dapat menjelaskan pengertian energi bunyi, $10(55 \%)$ orang siswa yang dapat menyebutkan 3 macam bunyi, $10(55 \%)$ orang siswa yang dapat menyebutkan 3 contoh sumber bunyi, $12(66 \%)$ orang siswa yang dapat menjelaskan manfaat dari pemantulan bunyi, 9 (50\%) orang siswa yang 4 contoh yang dapat menyerap benda pada permukaan lunak.

\section{Data Siklus 2 Aspek Guru dan Siswa}

Pada siklus kedua ini peneliti bertindak sebagai guru, yang melaksanakan pembelajaran di kelas, sedangkan guru mata pelajaran bertindak sebagai pengamat dan dibantu oleh 2 orang teman sejawat. Selanjutya pembelajaran dilanjutkan pada siklus kedua masih materi yang sama yaitu energi bunyi.

Dilihat dari siklus pertama tentang aktivitas guru dan siswa dalam proses pembelajaran energi bunyi dengan menggunakan pendekatan keterampilan proses, yang terdiri dari 8 tahap ini, masih banyak yang ditemukan kekurangan-kekurangan yang belum disampaikan 
secara jelas kepada siswa, dan guru meninjau kembali kekurangan yang belum dicapai semua kegiatan yang direncanakan dalam 8 tahap pendekatan keterampilan proses.

Kurangnya guru dalam mencapai indikator yang telah ditentukan, berpengaruh terhadap aktivitas siswa dalam peningkatan dan proses pembelajaran energi bunyi, untuk lebih jelasnya hasil aktivitas siswa dalam proses pembelajaran energi bunyi dengan menggunakan pendekatan keterampilan proses, dapat dilihat pada tabel 4.3 data dibawah ini.

Tabel 4.3 Data hasil aktivitas siswa dalam proses pembelajaran siklus dua

\begin{tabular}{|c|c|c|c|c|}
\hline No & Indikator & Frekuesi & Skor(\%) & Kualifikasi \\
\hline 1. & $\begin{array}{l}\text { Siswa mengemukakan pertanyaan tentang hal-hal apa } \\
\text { yang belum dimengerti, serta meminta siswa untuk } \\
\text { mengemukakan gagasan untuk memecahkan masalah }\end{array}$ & 18 & $100 \%$ & SB \\
\hline 2. & $\begin{array}{l}\text { Siswa melakukan kegiatan mengamati masalah yaitu } \\
\text { siswa mengumpulkan data atau informasi yang sesuai } \\
\text { dengan materi energi bunyi }\end{array}$ & 15 & $53 \%$ & $\mathrm{C}$ \\
\hline 3. & $\begin{array}{l}\text { Siswa mengolongkan-golongkan dan mengkalasifikasi } \\
\text { masalah berdasarkan data dan informasi awal yang telah } \\
\text { ditemukan untuk memecahkan masalah, yaitu } \\
\text { mengolongkan antara sumber energi bunyi }\end{array}$ & 18 & $100 \%$ & SB \\
\hline 4. & $\begin{array}{l}\text { Siswa mengemukakan pemahaman sementara terhadap } \\
\text { materi yang terkumpul berdasarkan data dan informasi } \\
\text { awal, kemudian menghubungkannya dengan kenyataan } \\
\text { yang ada dilingkungan sekitar }\end{array}$ & 13 & $72 \%$ & B \\
\hline 5. & $\begin{array}{l}\text { Siswa menyelidiki masalah dengan melakukan } \\
\text { percobaan untuk menguatkan pemahaman awal siswa } \\
\text { terhadap energi bunyi }\end{array}$ & 15 & $53 \%$ & $\mathrm{C}$ \\
\hline 6. & $\begin{array}{l}\text { Siswa meramalkan atau menyimpulkan kemungkinan } \\
\text { yang akan terjadi dari kegiatan menafsirkan yang telah } \\
\text { dilakukan, yaitu berupa pemahaman terhadap energi } \\
\text { bunyi }\end{array}$ & 15 & $53 \%$ & $\mathrm{C}$ \\
\hline 7. & $\begin{array}{l}\text { Siswa mengaplikasikan pemahamannya dalam bersikap } \\
\text { dan bertingkah laku serta mengkomunikasikan } \\
\text { pemahamannya dalam kegiatan bertanya, menjelaskan, } \\
\text { serta menyusun laporan, dari proses yang mereka } \\
\text { lakukan }\end{array}$ & 18 & $100 \%$ & SB \\
\hline 8. & Guru mengevaluasi dan menilai hasil kerja siswa & 18 & $100 \%$ & SB \\
\hline
\end{tabular}

Dari data tabel 4.3 keberhasilan siswa di atas menunjukan bahwa data aktivitas siswa dalam pembelajaran konsep energi bunyi dengan menggunakan pendekatan keterampilan proses yang terdiri dari 18 siswa pada siklus kedua menunjukan bahwa hanya 18 (100\%) siswa yang mengamati masalah sesuai dengan materi energi bunyi, 10 orang siswa (55\%) menggolongkan dan mengklasifikasi sumber energi bunyi, 15 orang siswa(53\%) pada siklus 1 menunjukan bahwa hanya 15 siswa (53\%) yang dapat menafsirkan masalah tentang materi yang diajarkan, 18 siswa(100\%) yang dapat meramalkan kegiatan yang dilakukan untuk melakukan percobaan, 13 siswa (53\%) yang bisa menerapkan pemahamannya tentang energi bunyi, 15 Siswa (53\%) yang bisa merencanakan apa yang dilakukan dalam percobaan, 18 siswa (100\%) yang mengkomunikasikan dan menyimpulkan pelajaran tentang materi yang dibawakan, 18 siswa (100\%) yang mengerjakan tes formatif.

Berdasarkan refleksi data aktivitas pada siklus kedua dapat disimpulkan bahwa pemahaman konsep energi bunyi melalui pendekatan keterampilan proses yang terdiri dari 8 tahap yaitu mengamati, menggolongkan/ 
mengkalsifikasi, menafsirkan, merencanakan penelitian, meramalkan, menerapkan, mengkomunikasikan, dan evaluasi dikategorikan cukup (C).

Aktivitas guru dan siswa pada siklus kedua ini, berpengaruh terhadap keberhasilan siswa dalam mengerjakan tes formatif akhir siklus 2 dalam meningkatkan konsep energi bunyi hal ini menjelaskan pengertian energi bunyi, menyebutkan 3 macam bunyi, menyebutkan 3 contoh sumber energi bunyi,menjelaskan fungsi pemantulan bunyi, dan 4 contoh benda yang dapat menyerap pada permukaan lunak, dalam menggunakan pendekatan keterampilan proses dapat dilihat pada tabel 4.4 dibawah ini

Tabel 4.4 Data Hasil Belajar Siswa Siklus Dua

\begin{tabular}{llccc}
\hline No & Pemahaman siswa terhadap konsep energi bunyi & Frekuensi & Presentase & Kualifikasi \\
\hline 1. & Mampu menjelaskan pengertian energi bunyi & 18 & $100 \%$ & SB \\
\hline 2. & Mampu menyebutkan 3 macam bentuk energi & 18 & $100 \%$ & SB \\
\hline 3. & Mampu menyebutkan 3 contoh energi & 17 & $85 \%$ & B \\
\hline 4. & Mampu menjelaskan manfaat pemantulan bunyi & 17 & $85 \%$ & B \\
\hline 5. & $\begin{array}{l}\text { Mampu menentukan 4 contoh yang dapat menyerap } \\
\text { pada permukaan lunak }\end{array}$ & 17 & $85 \%$ & B \\
\hline
\end{tabular}

Dari tabel 4.4 di atas menunjukan bahwa dalam peningkatan pemahaman konsep energi bunyi dengan menggunakan pendekatan keterampilan proses dari 18 orang siswa. Pada siklus kedua Data hasil tes formatif 2 tindakan siklus 2 yang diberikan, yakni satu orang siswa memperoleh nilai 80, lima orang siswa memperoleh nilai 90, dan dua belas orang memperoleh nilai 100. Dari yang diperoleh siswa dipresentasikan dengan nilai rata-rata 96,11\%.

Hasil penelitian yang terdiri dari aktivitas guru dan siswa dalam meningkatkan pemahaman siswa dalam memahami materi konsep energi bunyi dalam menggunakan pendekatan keterampilan proses melalui 8 tahapan yakni, mengamati, menggolongkan/mengkalsifikasi, menafsirkan, merencanakan penelitian, meramalkan, dan menerapkan, mengkomunikasikan, dan eveluasi dari siklus pertama, kedua mengalami peningkatan yang signifikan.

Hasil tindakan siklus pertama belum mencapai hasil yang diharapkan karena belum sejalan dengan teori-teori pembelajaran konsep energi bunyi. Pembelajaran konsep energi bunyi ini yang terdiri dari : melalui ceramah siswa dapat menjelaskan pengertian energi bunyi dengan benar. melalui gambar siswa dapat menyebutkan 3 macam bunyi dengan baik. melalui tanya jawab siswa dapat menyebutkan 3 contoh sumber energi bunyi dengan benar. melalui ceramah, siswa dapat menjelaskan fungsi pemantulan bunyi dengan benar. melalui tanya jawab, siswa dapat menyebutkan 3 contoh benda yang dapat menyerap bunyi pada permukaan lunak dengan benar. Pemahaman siswa tentang konsep energi bunyi, dalam siklus 1 masih banyak siswa ditemukan belum mengerti, ketidak mengertian siswa diakibatkan guru dalam membawakan materi pembelajaran masih banyak indikator yang belum disampaikan.

Guru dalam menyampaikan proses pembelajaran melalui pendekatan keterampilan proses yang terdiri dari 8 tahap ini, belum mencapai indikator yang ditetapkan diantaranya guru belum menyampaikan langkah-langkah pembelajaran yang jelas, butir indikator yang belum dilakukan guru adalah guru tidak membimbing siswa untuk menerapkan peristiwa antara energi bunyi dalam kehidupan sehari-hari, guru tidak membimbing siswa untuk menafsirkan setiap kelompok untuk mencatat hasil pengamatan siswa, guru tidak membimbing siswa dalam mengunakan alat peraga dengan baik, guru tidak membimbing siswa dalam mengadakan percobaan, guru tidak membimbing siswa untuk menarik kesimpulan setelah melakukan percobaan setiap perkelompok, guru tidak membimbing siswa untuk melakukan tanya jawab.

Dalam pembelajaran ini siswa berpendapat bahwa cara guru mengajar di kelas dapat dimengerti dengan mudah dan sangat menyenangkan. Siswa merasa bahwa langkahlangkah yang dilakukan guru dalam mengajar dapat memotivasi siswa untuk cepat mengerti dan memahami materi pembelajaran. Selain itu, siswa 
juga merasa tidak terbebani dalam mempelajari, karena merasa tidak terbebani dalam mempelajari materi, karena merasa kebebasan berfikirnya dihargai. Di samping itu, semua aktivitas yang dilakukan siswa, hanya diarahkan dan diberikan bimbingan seperlunya. Hal ini sesuai pendapat Suparno (2001: 44) "bahwa pengetahuan yang diperoleh siswa selama pembelajaran merupakan hasil bentukan siswa itu sendiri".

Dalam pembelajaran tindakan siklus pertama guru belum mampu melaksanakan pembelajaran secara optimal, ketiga tahapan pembelajaran konsep energi bunyi dengan menggunakan pendekatan keterampilan proses belum mampu diaplikasikan dengan baik sehingga berdampak pada peningkatan pemahaman siswa dalam memahami materi belum sesuai yang diharapkan, sebagaimana dilihat dari pemahaman siswa dalam mengemukakan jawaban dari soal yang diberikan secara tulisan, belum sesuai dengan kriteria keberhasilan yang ditetapkan yaitu $70 \%$ dengan nilai paling rendah 6 .

Pada tindakan siklus 2 keberhasilannya sudah mencapai target yang diinginkan, hal ini dilihat dari jawaban siswa pada LKS, dan tes formatif sudah sesuai dengan kriteria keberhasilan yang ditetapkan, dimana dalam pembelajaran pada tindakan siklus 2 ini juga menerapkan pendekatan keterampilan proses sebagai upaya meningkatkan pemahaman siswa dalam memahami materi konsep energi bunyi, dengan langkah-langkah pembelajaran yakni (1) mengenalkan kepada siswa tentang materi atau permasalahan yang akan dikerjakan, (2) mengelolah pengetahuan awal siswa terhadap materi dengan melakukan apersepsi, (3) membimbing siswa untuk menyelidiki baik secara individu maupun kelompok, dan (4) mengingatkan kembali kepada siswa tentang kegiatan yang dilakukan serta melakukan evaluasi, serta menyimpulkan isi pelajaran. Hal ini sejalan dengan pendapat (Nurhadi, 2006: 14) mengemukakan bahwa salah satu upaya untuk meningkatkan pemahaman siswa dalam memahami materi, yaitu dengan menerapkan pembelajaran pendekatan keterampilan proses kepada siswa dengan langkah-langkah pembelajaran.

Pada siklus pertama ini siswa belum menyadari bahwa dalam belajar konsep energi bunyi masih banyak siswa yang kurang mengerti dengan apa yang dijelaskan guru, harus memperlihatkan benda-benda konkret dan guru membawakan materi jangan terlalu cepat.

Sehingga keberhasilan siklus satu ini mencapai kualifikasi cukup (c) dalam proses peningkatan pembelajaran energi bunyi melalui pendekatan keterampilan proses yang terdiri dari delapan tahap ini pada siklus berikutnya agar lebih meningkat, guru lebih mengutamakan indikator yang belum tercapai dalam pembelajaran siklus satu sehingga rata-rata dipresentasekan dalam tes formatif satu mencapai $63,88 \%$.

Dalam pembelajaran tindakan siklus 2 guru sudah mampu melaksanakan pembelajaran secara optimal, ketiga tahapan pembelajaran konsep energi bunyi khususnya sumber energi bunyi dengan menggunakan pendekatan keterampilan proses sudah mampu diaplikasikan dengan sangat baik, diberi kulifikasi sangat baik (B). Sehingga berdampak pada peningkatan pemahaman siswa dalam memahami materi, dimana pada tindakan siklus kedua ini pemahaman siswa dalam memahami materi sudah sesuai dengan yang diharapkan, sebagaimana dilihat dari pemahaman siswa dalam mengemukakan jawaban dari tes formatif yang diberikan secara tulisan, sudah sesuai dengan kriteria keberhasilan yang diberikan secara tulisan, sudah sesuai dengan kriteria keberhasilan yang telah ditetapkan yaitu $70 \%$ dengan nilai paling rendah 6 . Pada tindakan siklus kedua guru mampu melaksanakan semua indikator dengan baik yang telah direncanakan. Pemahaman siswa dalam mengemukakan jawaban tes formatif, dipresentasekan secara keseluruhan dari sabjek penelitian pemahaman materi mencapai 96,11\%.

Pada tindakan siklus kedua ini pemahaman siswa dalam memahami materi sudah sesuai dengan yang diharapkan peneliti, sebagaimana dilihat dari pemahaman siswa dalam mengemukakan jawaban dari tes formatif yang diberikan secara tulisan, sudah sesuai dengan kriteria keberhasilan yang telah ditetapkan yaitu $70 \%$ dengan nilai paling rendah 6 .

Keberhasilan siklus dari tindakan ketindakan karena guru dapat melaksanakan rancangan pembelajaran dengan baik sesuai dengan pendekatan yang digunakan, serta kesesuaian dan ketepatan pendekatan yang digunakan yaitu pendekatan keterampilan proses dalam meningkatkan pemahaman siswa dalam memahami materi konsep energi bunyi mengalami 
peningkatan yang sangat baik. Tujuan pembelajaran yang ditetapkan telah tercapai dengan baik, siswa juga sudah mampu menemukan tingkat kemampuan dalam kehidupan keseharian dengan lingkungannya, pemahaman siswa terbangun dalam memahami materi, dimana guru mengaitkan antara materi dengan keseharian siswa. Berdasarkan evaluasi hasil pada pelaksanaan pembelajaran dengan pendekatan keterampilan proses, ditemukan bahwa pada dasarnya pendekatan ini memiliki potensi yang cukup baik untuk untuk meningkatkan pemahaman siswa terhadap materi energi bunyi. Hal ini ditunjukan oleh rata-rata hasil tes akhir subjek penelitian yang dilaksanakan pada setiap pembelajaran mengalami peningkatan. Dengan demikian, pendekatan keterampilan proses merupakan pendekatan yang dapat meningkatkan pemahaman siswa terhadap IPA khususnya dalam memahami konsep energi bunyi.

Pemahaman siswa yang baik terhadap konsep energi bunyi mengindikasikan bahwa pendekatan keterampilan proses memungkinkan untuk dijadikan sebagai salah satu model pembelajaran dalam meningkatkan prestasi siswa dalam IPA khususnya di SD.

\section{SIMPULAN DAN SARAN}

Berdasarkan penelitian yang disajikan dalam BAB IV dapat diambil kesimpulan bahwa penggunaan pendekatan keterampilan proses dalam proses pembelajaran konsep energi bunyi pada SD Negeri 110 Pompanua mengalami peningkatan. Hal ini terbukti adanya perkembangan aktifitas siswa dari siklus pertama dengan kualifikasi cukup(C) pada siklus kedua menjadi kualifikasi baik (B). Berdasarkan hasil observasi, pelaksanaan, pengamatan, evaluasi, dan refleksi maka dapat disimpulkan bahwa pendekatan keterampilan proses dapat meningkatkan pemahaman konsep pada siswa Kelas VI SD Negeri 110 Pompanua. Pencapaian pemahaman konsep energi bunyi pada siswa sudah sesuai yang diharapkan sebab telah memenuhi aspek tingkat penguasaan siswa dalam ketulusan belajar siswa.

Berdasarkan temuan penelitian yang telah disajikan pada BAB IV maka disarankan:

1. Kepada rekan guru SD, agar menggunakan pendekatan keterampilan proses sebagai salah satu alternatif meningkatkan pemahaman konsep dalam pembelajaran energi bunyi di SD.

2. Kepada pihak guru yang menerapkan pendekatan keterampilan proses disarankan selama proses belajar mengajar berlangsung, siswa didudukan dalam kelompoknya, sehingga siswa yang mengalami kesulitan dalam memahami materi ketika disajikan dapat segera memperoleh bantuan dari teman kelompoknya. Hal ini lebih menguntungkan karena siswa sering tidak berani bertanya kepada guru apabila mengalami kesulitan.

3. Kepada semua calon guru diharapkan dalam melakukan pembelajaran di SD agar diperhatikan memilih pendekatan yang cocok sehingga dalam proses pembelajaran sesuai dengan indikator yang dicapai.

\section{DAFTAR RUJUKAN}

Ardhana, Alfianati. 1999. Instrumen Ilmu Sains di Sekolah Dasar. Jakarta: Bima Cipta.

Arikunto, Suharsimi, dkk.2006. Penelitian Tindakan Kelas. Jakarta PT Bumi Aksara

Bundu, Patta. 2006. Penilaian Keterampilan Proses dan Sikap Ilmiah dalam Pembelajran Sains di Sekolah Dasar. Jakarta Depdiknas. Direktorl Jenderal Pendidikan Tinggi. Direktorat Ketenagaan

Dimyati, dkk. 1996. Belajar dan Pembelajaran. Jakarta: Depdikbud.

Hadiat, dkk. 1996. Metodologi Ilmu Pengetahuan. Bandung: Depdikbud.

Hafid, Abdulah. 1996. Studi Kemampuan Guru SD Menerapkan Pendekatan Keterampilan Proses Dalam Pengajaran IPA Kelas VI SD Kecamatan Suka Sari Kota Madya Bandung. Bandung: FakultasPendidikan Matematika dan IPA dan Institut Keguruan dan Ilmu Pendidikan.

Haryanto. 2006. Sains untuk Sekolah Dasar Kelas VI. Jakarta: Erlangga

Khaeruddin, dkk. 2005. Pembelajaran Sains (IPA) berdasarkan Kurikulum Berbasis Kompetensi. Makassar: State University of Makassar Pres.

Kurikulum Tingkat Satuan Pendidikan (KTSP), 2006. Mata pelajaran IPA untuk Tingkat SD/MI. Jakarta Depdiknas. 
Madya, S. 1994. Panduan Penelitian Tindakan. Yogiakarta: Lembaga Penelitian IKIP Yogyakarta

Mangunwijaya. 1998. Berbagai pendekatan Proses Belajar Mengajar. Jakarta : Bumi Aksara.

Miles, M.B dan Huberman. 1992. Analisis Data Kuantitatif. Terjemahan oleh Tjetjep Rohudi Rihidi. Jakarta: UI Perss.

Moedjino, dkk. 1991/1992. Strategi Belajar Mengajar. Jakarta: Departemen Pendidikan dan Kebudayaan/Direktorat Jenderal Pendidikan Tinggi dan Direktorat Ketenagaan.

Moleong, L.J. 1994. Metodologi Penelitian Kuantitatif. Bandung: Remaja Rosdakarya.

Nurkanca. 1986. Evaluasi pendidikan. Surabaya: Usaha Nasional

Purba dan Wartono. 1998. Strategi Belajar Mengajar Pendidikan Sains. Bandung: Remaja Rosdakarya.

Rifai, Arman. 1998. Strategi Belajar Mengajar Pendidikan Sains. Bandung: Remaja Rosdakarya.

Sidharta, Priguna. 1998. Metode Inkuiri Dalam Pembelajaran Sains. Jakarta: Rajawali Pers.

Semiawan, dkk. 1986. Pendidikan Keterampilan Proses. Jakarta: Gramedia.

Sumatowa, Usman, 2006. Bagaimana Membelajarkan IPA Di Sekolah Dasar. Jakarta: Depdiknas. Direktorat Jenderal.

Sumardi, Yosaphat, dkk. 2007. Konsep Dasar IPA. Jakarta: Universitas Terbuka.

Taggart. 1998. Theaction Research Plamer. Deaking Universitas Press. 